\title{
Evaluation of a Glaze Polishing Technique for Pigmented Denture Acrylic Resin Submitted to Thermocycling and Disinfection
}

\author{
Marcelo Coelho Goiato ${ }^{1}$, Mariana Vilela Sônego', Denise de Barros Carneiro', Emily Vivianni Freitas da Silva1', Liliane da Rocha Bonatto², \\ Elidiane Cipriano Rangel ${ }^{3}$, Daniela Micheline dos Santos ${ }^{1}$ \\ ${ }^{1}$ Department of Dental Materials and Prosthodontics, Aracatuba Dental School, Unesp Univ Estadual Paulista, Aracatuba, São Paulo, ${ }^{2}$ Private Practice, \\ Cascavel, Parana, ${ }^{3}$ Department of Techonological Plasmas, Univ Estadual Paulista, Sorocaba, Brazil
}

\section{Abstract}

\begin{abstract}
Aims: Compare the mechanical and physical properties of two polishing techniques for acrylic resins under the influence of disinfection. Materials and Methods: Two hundred and eight circular samples (10 mm diameter $\times 3 \mathrm{~mm}$ height) were manufactured, with 160 for the color stability, hardness, surface roughness, and wettability $(n=10)$ analyses, and 48 for the scanning electron microscopy and atomic force microscopy evaluation $(n=1)$. Two brands of prosthesis acrylic resin, Onda Cryl and Lucitone, were used to manufacture the samples. Half of the samples were intrinsically pigmented with a purple acrylic pigment (Policor) at $7 \%$ of the total weight in powder; half of those received the mechanical polish with sand paper under constant water irrigation in a universal polishing machine at $300 \mathrm{rpm}$ (control), and half received a uniform coat of a photopolymerized glaze (Megaseal) to be tested. The samples were kept immersed in distilled water for $24 \mathrm{~h}$ before the initial measurements (T0), afterward, they were divided into two disinfection procedures; half were disinfected through microwave energy and half through cleaning tablets (Efferdent) for 60 days (T1). Results: The glaze polished groups presented inferior chromatic stability and the pigments prevented discoloration for the glaze polish. The disinfectant solutions promoted a superficial degradation of the acrylic resin for both polishing techniques. Lucitone presented higher hardness values than Onda Cryl $(P<0.001)$ and the glaze technique had higher hardness values than the mechanic polish. Conclusion: The photopolymerized glaze improved some characteristics of the acrylic resin, such as the surface hardness and roughness suggesting it is an adequate polish for acrylic resins.
\end{abstract}

Keywords: Acrylic resins, dental polishing, disinfection, pigmentation

\section{INTRODUCTION}

Acrylic resin is the most commonly used material to manufacture conventional removable prostheses; it is a low-cost material, has good adaptability to oral tissue, it is easy to manipulate, and possesses satisfactory esthetic characteristics. ${ }^{[1-3]}$

The acrylic resin must mimic the soft tissue features to provide an excellent esthetic outcome, ${ }^{[4]}$ and there are two techniques to do so: An extrinsic characterization in which the pigments are added after the polymerization process; and an intrinsic characterization in which the pigments are incorporated into the acrylic before the polymerization. The intrinsic technique provides good results since pigmentation is internal. The pigments age with the prosthetic material and are not influenced by damage on the prosthesis surface. ${ }^{[2]}$

\begin{tabular}{|l|l|}
\hline \multicolumn{2}{|c|}{ Access this article online } \\
\hline Quick Response Code: & Website: \\
\hline & www.jioh.org \\
\hline & \\
\hline
\end{tabular}

Some physical properties are directly linked to material longevity, such as microhardness, surface roughness, and color stability. These properties can be influenced through time due to constant temperature changes, contact to wet oral tissues, the disinfection process used, and contact to different solutions..$^{[1,5-13]}$

Different polishing techniques have been used in an attempt to improve these characteristics; the polish can be mechanical, performed with different polishing pastes and soft brushes, or

Address for correspondence: Prof. Marcelo Coelho Goiato, Department of Dental Materials and Prosthodontics, Unesp Univ Estadual Paulista, Aracatuba, São Paulo, Brazil. E-mail: goiato@foa.unesp.br

This is an open access article distributed under the terms of the Creative Commons Attribution-NonCommercial-ShareAlike 3.0 License, which allows others to remix, tweak, and build upon the work non-commercially, as long as the author is credited and the new creations are licensed under the identical terms.

For reprints contact: reprints@medknow.com

How to cite this article: Goiato MC, Sônego MV, Carneiro DD, da Silva EV, Bonatto LD, Rangel EI, et al. Evaluation of a glaze polishing technique for pigmented denture acrylic resin submitted to thermocycling and disinfection. J Int Oral Health 2017;9:213-21. 
chemical, in which the acrylic prosthesis is immersed in the heated monomer. ${ }^{[14,15]}$ Now, a new method has been reported in published literature; a surface coating with a photopolymerized glaze. ${ }^{[9,10]}$

Dental materials suffer constant degradation during the rehabilitation process and clinical use, which can lead to a modification in their mechanical and physical properties. ${ }^{[16]}$ Constant contact with humidity and alternating temperatures in the oral cavity are examples of stress on the material. In addition, contact to pigmented food, and the disinfection applied, can increase the amount of stress and induce further degradation characteristics. ${ }^{[2,3,17]}$

The disinfection of complete prostheses can be performed with chlorhexidine gluconate, sodium hypochlorite, alkali, and peroxide solutions, as well as with microwave energy. ${ }^{[2,3,17-19]}$ Chlorhexidine gluconate and effervescent tablets are effective in the reduction of microorganisms, but can induce a surface degradation. ${ }^{[18]}$ Microwave disinfection was proven effective against candida species, however, it was associated to color and hardness changes in acrylic resin. ${ }^{[2,3,17,19]}$ Yet, microwave energy and effervescent tablets are the most accessible disinfection techniques with satisfactory microorganism reduction.

Oral fluids and disinfection procedures play important roles in the longevity of complete prostheses. There are many reports in published literature correlating thermocycling and disinfectant solutions with different properties of acrylic resin. ${ }^{[1,3,8,12,17,20-22]}$ Yet, there are no known reports on the glaze polishing technique associated with acrylic resin for complete prostheses, considering the effect of thermocycling or disinfection procedures. Therefore, the aim of this study was to evaluate a photopolymerized glaze coating as a final polishing technique for pigmented complete prosthesis acrylic resins, under the influence of thermocycling and two disinfection procedures.

\section{Materials and Methods}

Two prosthesis heat cured acrylic resins (Onda Cryl, Classico LTDA, and Lucitone 550, Dentsply) and a purple characterization pigment (Policor, Classico LTDA) were used in the present study to evaluate a surface polishing technique. Two polishing techniques were applied: the mechanical as a control and a photopolymerized glaze coat. The clinical use through disinfection was also simulated, and the samples were submitted to two disinfection methods, either by microwave energy or immersion in cleaning tablets (Efferdent).

Two hundred and eight circular specimens $(10 \mathrm{~mm}$ in diameter and $3 \mathrm{~mm}$ thick) were manufactured and divided into 16 groups. One hundred and sixty samples were used for the hardness, surface roughness, color stability, and surface energy analyses $(n=10)$, and 48 for atomic force microscopy (AFM) and MEV images $(n=1)$. One hundred and four were used for each type of resin, varying the pigmentation (52 samples were pigmented) and the polishing technique ( 52 were mechanically polished and 52 received a glaze coat).
A perforated metallic matrix was cast inside prosthesis flasks with type IV dental stone. The acrylic resins were weighted and manipulated according to the manufacturer's instructions. Six percent of the resin powder total weight in pigments were added to the pigmented groups during the manipulation, then the mix was inserted into the metallic matrix, and the curing cycle was initiated after a $30 \mathrm{~min}$ interval. The Lucitone 550 flasks were put in a hot water bath at $73^{\circ} \mathrm{C}$ for $90 \mathrm{~min}$ and immediately after, in boiling water for $30 \mathrm{~min}$. The Onda Cryl specimens were microwave cured for $10 \mathrm{~min}(3 \mathrm{~min}$ at $30 \%$ power, $4 \mathrm{~min}$ at $0 \%$ power, and $3 \mathrm{~min}$ at $60 \%$ power).

After the flasks had cooled, the specimens were removed from the metallic matrix and the excess trimmed with tungsten burs. They were then polished with a sandpaper sequence (grit 600 and 800) under constant water irrigation in a universal polishing machine at $300 \mathrm{rpm}$ (Ecomet 300pro; Buehler, Illinois, USA). The thickness of the specimens was regularly measured with a digital caliper (500-171-20b, Mitutoyo, Tokyo, Japan) to standardize their size. ${ }^{[6]}$

The mechanical polish samples were then submitted to 1200 grit sandpaper and a diamond solution on felt disc. The glaze finished groups received a uniform layer of Megaseal glaze (Megadenta, Radeberg, Germany) on the surface of the samples, and were then photopolymerized for 180 s by a strobe light (EDG Equipment, Sao Carlos, Brazil). When both polishing techniques were complete, the specimens were sonicated in distilled water for $20 \mathrm{~min}$ to eliminate possible surface debris. All samples were then immersed in distilled water at $37^{\circ} \mathrm{C}$ for $24 \mathrm{~h}$ before the first testing period (T0). The tests were repeated after the disinfection (T1). ${ }^{[6]}$

The specimens remained immersed in distilled water in hermetically sealed containers at a controlled temperature of $35^{\circ} \mathrm{C} \pm 2{ }^{\circ} \mathrm{C}$ for 60 days, during which the disinfection was conducted. The selected groups were disinfected every 3 days, either by microwave energy or immersion in disinfection tablets. The Efferdent group was immersed in $250 \mathrm{ml}$ of warm water with the effervescent tablet for $15 \mathrm{~min}$, according to the manufacturer's instructions, and the microwave groups were immersed in $200 \mathrm{ml}$ of distilled water and microwaved at $650 \mathrm{~W}$ of radiation for $6 \mathrm{~min}$.

The specimens were submitted to color stability, surface hardness, surface roughness (Rt), and wettability analysis. To evaluate the effects of the polishing techniques on the surface of the prosthesis base resins, one specimen of each group was selected and tested with scanning electron microscopy (SEM) and AFM.

Color alterations were calculated with the $\mathrm{L} * \mathrm{a} * \mathrm{~b} *$ system, established by the Commission Internationale de l'Eclairage, in an ultraviolet-visible reflection spectrophotometer (model UV-2450, Shimadzu Corporation, Kyoto, Japan). Knoop microhardness was determined according to the American Society for Testing and Materials specification E384-1128, using a microhardener (HMV-2T; Shimadzu Corporation) 
Goiatoa, et al:: Glaze polishing technique for acrylic resin

with a $25 \mathrm{~g}$ load for $10 \mathrm{~s}$. Surface roughness evaluation (Rt values) was performed through profilometry with a Surtronic 25 (Taylor Hobson) profilometer calibrated with a cutoff filter of $500 \mu \mathrm{m}$, an evaluation length of $1.25 \mathrm{~mm}$, and a range of $100 \mathrm{~mm}$.

The surface wettability was evaluated through surface energy analysis of the acrylic disks. The sessile drop technique was used in a temperature-controlled room, and ten measurements were repeated per specimen. Drops of 2 liquids with different polarities, deionized water, which represents polar components, and diiodomethane, featuring dispersive elements, were deposited in a controlled manner on the specimen surface, and then placed horizontally on a goniometer (Ramé-Hart 100-00; Ramé-Hart Instrument Co). Through software (DROPimage Standard; Ramé-Hart Instrument $\mathrm{Co}$ ), the contact angle formed between the drop of each liquid to the acrylic resin was measured. The calculation of surface energy was performed according to the Owens-Wendt-Rabel-Kaelble method. ${ }^{[23]}$

\section{Statistical analysis}

The IBM SPSS 20.0 (IBM, United States) was used to assess the effects of different types of acrylic resin, the polishing technique applied, the period of evaluation, and the presence of pigment, were submitted to the analysis of variance (ANOVA). Significant differences were compared by the Tukey HSD test $(\alpha=0.05)$.

\section{RESULTS}

\section{Color stability}

The ANOVA analysis presented a significant difference for the pigment $\times$ polish interaction [Table 1]. The Student's $t$ post-test analysis showed that the glaze polished groups presented inferior chromatic stability [Table 2].

Table 3 indicates that the glaze polished groups without pigment presented a statistical difference regarding chromatic stability, while the glaze polished with pigment group presented the higher $\Delta \mathrm{E}$ results.

\section{Surface roughness (Rt)}

In contrast to color stability, the hardness, and all subsequent analyses had two periods of evaluation (T0 - baseline, T1 - disinfection). Table 4 demonstrates that the polish, disinfection, and period factors, and the interactions of resin $\times$ disinfection, polish $\times$ disinfection, period $\times$ polish, period $\times$ resin $\times$ polish, period $\times$ pigment $\times$ disinfection, period $\times$ polish $\times$ disinfection statistically interfered in the roughness results.

The glaze polished groups presented higher surface roughness results and the disinfection increased the roughness, with the Efferdent group presenting higher roughness values [Table 5].

\section{Surface hardness}

The variables that presented a significant difference for surface hardness were period, polish, resin, and

\begin{tabular}{|c|c|c|c|c|c|}
\hline Variation & SS & df & MS & $F$ & $P$ \\
\hline Resin & 1.809 & 1 & 1.809 & 0.556 & 0.457 \\
\hline Pigment & 3.531 & 1 & 3.531 & 1.086 & 0.299 \\
\hline Polish & 59.034 & 1 & 59.034 & 18.154 & $<0.001 *$ \\
\hline Disinfection & 9.413 & 1 & 9.413 & 2.895 & 0.091 \\
\hline Resin $\times$ pigment & 3.600 & 1 & 3.600 & 1.107 & 0.294 \\
\hline Resin $\times$ polish & 1.057 & 1 & 1.057 & 0.325 & 0.569 \\
\hline Resin $\times$ disinfection & 0.181 & 1 & 0.181 & 0.056 & 0.814 \\
\hline Pigment $\times$ polish & 23.778 & 1 & 23.778 & 7.312 & $0.008^{*}$ \\
\hline Pigment $\times$ disinfection & 0.012 & 1 & 0.012 & 0.004 & 0.952 \\
\hline Polish $\times$ disinfection & 0.076 & 1 & 0.076 & 0.023 & 0.879 \\
\hline Resin $\times$ pigment $\times$ polish & 1.638 & 1 & 1.638 & 0.504 & 0.479 \\
\hline Resin $\times$ pigment $\times$ disinfection & 0.306 & 1 & 0.306 & 0.094 & 0.760 \\
\hline Resin $\times$ polish $\times$ disinfection & 1.587 & 1 & 1.587 & 0.488 & 0.486 \\
\hline Pigment $\times$ polish $\times$ disinfection & 1.178 & 1 & 1.178 & 0.362 & 0.548 \\
\hline $\begin{array}{l}\text { Resin } \times \text { pigment } \times \text { polish } \times \\
\text { disinfection }\end{array}$ & 1.650 & 1 & 1.650 & 0.507 & 0.477 \\
\hline Error & 468.270 & 144 & 3.252 & & \\
\hline Total & 2047.044 & 160 & & & \\
\hline
\end{tabular}

Table 2: Mean values and standard deviation of color change $(\Delta \mathrm{E})$ according to the polish, independent of resin, pigment and disinfection

\begin{tabular}{lc}
\hline Polish & Color change \\
\hline Mechanic & $2.42(1.72)^{\mathrm{B}}$ \\
Glaze & $3.64(1.90)^{\mathrm{A}}$ \\
\hline
\end{tabular}

Means followed by the same capital letter in the column do not difference $(P<0.05$, Student $t$-test $)$

Table 3: Mean values and standard deviation of color change $(\Delta \mathrm{E})$ according to polish and pigments

\begin{tabular}{lcc}
\hline Pigment & Mechanic & Glaze \\
\hline Without pigment & $2.19(1.83)^{\mathrm{A}, \mathrm{b}}$ & $4.17(1.84)^{\mathrm{A}, \mathrm{b}}$ \\
With pigment & $2.66(1.59)^{\mathrm{A}, \mathrm{b}}$ & $3.10(1.81)^{\mathrm{B}, \mathrm{a}}$ \\
\hline
\end{tabular}

Means followed by the same capital letter in the column and the same lowercase letter in the line do not difference $(P<0.05$, Tukey)

the interactions of resin $\times$ polish, period $\times$ polish and period $\times$ resin $\times$ pigment [Table 6]. Table 7 presents the ANOVA results for the surface hardness. Table 8 indicates that Lucitone presented higher hardness results than Onda Cryl, and demonstrates that the glaze polished groups had higher hardness values. There was a decrease in hardness after disinfection for both polishing techniques and resins, and the glaze polish maintained higher hardness values even after the disinfection period [Table 9].

\section{Surface energy}

Table 10 presents the ANOVA results for the surface energy assay. It was observed that the period and disinfection factors, as well as the interactions of resin $\times$ polish $\times$ disinfection, 
Goiatoa, et al.: Glaze polishing technique for acrylic resin

\begin{tabular}{|c|c|c|c|c|c|}
\hline Variation & SS & df & MS & $F$ & $P$ \\
\hline Resin & 1.724 & 1 & 1.724 & 3.103 & 0.080 \\
\hline Pigment & 0.211 & 1 & 0.211 & 0.379 & 0.539 \\
\hline Polish & 9.038 & 1 & 9.038 & 16.263 & $<0.001^{*}$ \\
\hline Disinfection & 4.355 & 1 & 4.355 & 7.836 & $0.006^{*}$ \\
\hline Resin $\times$ pigment & 0.015 & 1 & 0.015 & 0.027 & 0.869 \\
\hline Resin $\times$ polish & 0.013 & 1 & 0.013 & 0.024 & 0.877 \\
\hline Resin $\times$ disinfection & 3.797 & 1 & 3.797 & 6.833 & $0.010^{*}$ \\
\hline Pigment $\times$ polish & 1.515 & 1 & 1.515 & 2.726 & 0.101 \\
\hline Pigment $\times$ disinfection & 0.543 & 1 & 0.543 & 0.977 & 0.325 \\
\hline Polish $\times$ disinfection & 3.209 & 1 & 3.209 & 5.775 & $0.018^{*}$ \\
\hline Resin $\times$ pigment $\times$ polish & 0.127 & 1 & 0.127 & 0.228 & 0.634 \\
\hline Resin $\times$ pigment $\times$ disinfection & 1.137 & 1 & 1.137 & 2.045 & 0.155 \\
\hline Resin $\times$ polish $\times$ disinfection & 0.010 & 1 & 0.010 & 0.017 & 0.896 \\
\hline Pigment $\times$ polish $\times$ disinfection & 0.108 & 1 & 0.108 & 0.194 & 0.660 \\
\hline Resin $\times$ pigment $\times$ polish $\times$ disinfection & 0.004 & 1 & 0.004 & 0.008 & 0.929 \\
\hline Between samples & 80.026 & 144 & 0.556 & & \\
\hline Period & 7.531 & 1 & 7.531 & 10.524 & $0.001 *$ \\
\hline Period $\times$ resin & 1.452 & 1 & 1.452 & 2.029 & 0.156 \\
\hline Period $\times$ pigment & 0.799 & 1 & 0.799 & 1.117 & 0.292 \\
\hline Period $\times$ polish & 3.292 & 1 & 3.292 & 4.601 & $0.034 *$ \\
\hline Period $\times$ disinfection & 0.970 & 1 & 0.970 & 1.355 & 0.246 \\
\hline Period $\times$ resin $\times$ pigment & 0.102 & 1 & 0.102 & 0.143 & 0.706 \\
\hline Period $\times$ resin $\times$ polish & 6.084 & 1 & 6.084 & 8.502 & $0.004 *$ \\
\hline Period $\times$ resin $\times$ disinfection & 0.525 & 1 & 0.525 & 0.733 & 0.393 \\
\hline Period $\times$ pigment $\times$ polish & 2.101 & 1 & 2.101 & 2.936 & 0.089 \\
\hline Period $\times$ pigment $\times$ disinfection & 6.107 & 1 & 6.107 & 8.535 & $0.004 *$ \\
\hline Period $\times$ polish $\times$ disinfection & 3.647 & 1 & 3.647 & 5.096 & $0.025^{*}$ \\
\hline Period $\times$ resin $\times$ pigment $\times$ polish & 0.750 & 1 & 0.750 & 1.048 & 0.308 \\
\hline Period $\times$ resin $\times$ pigment $\times$ disinfection & 0.656 & 1 & 0.656 & 0.917 & 0.340 \\
\hline Period $\times$ resin $\times$ polish $\times$ disinfection & 1.555 & 1 & 1.555 & 2.173 & 0.143 \\
\hline Period $\times$ pigment $\times$ polish $\times$ disinfection & 0.745 & 1 & 0.745 & 1.040 & 0.309 \\
\hline Period $\times$ resin $\times$ pigment $\times$ polish $\times$ disinfection & 1.267 & 1 & 1.267 & 1.771 & 0.185 \\
\hline Inter samples & 103.048 & 144 & 0.716 & & \\
\hline
\end{tabular}

${ }^{*} P<0.05$ means statistical difference. SS: Sum of square, MS: Mean of square

Table 5: Mean values and (standard deviation) of surface roughness with according to the polish, independent of resin, pigment, disinfection period

\begin{tabular}{ll}
\hline Polish & Roughness \\
\hline Mechanic & $2.06(0.83)^{\mathrm{B}}$ \\
Glaze & $2.40(0.89)^{\mathrm{A}}$ \\
\hline
\end{tabular}

Means followed by the same capital letter in the column do not difference $(P<0.05$, Student $t$-test $)$

period $\times$ resin $\times$ pigment, period $\times$ resin $\times$ polish, period $\times$ resin $\times$ disinfection, period $\times$ pigment $\times$ polish, period $\times$ polish $\times$ disinfection, period $\times$ resin $\times$ pigment $\times$ polish, period $\times$ pigment $\times$ polish $\times$ disinfection and period $\times$ resin $\times$ pigment $\times$ polish $\times$ disinfection, were statistically significant.

It was observed that there was an increase of the surface energy after the disinfection (period) and that the Efferdent disinfection promoted higher surface energy values [Table 11].

\section{Discussion}

The null hypothesis that the polishing technique would not affect the mechanical properties of prosthesis acrylic resins was not accepted, since the glaze polish presented poor characteristics after the disinfection process.

Chromatic changes can be related to extrinsic and intrinsic factors. ${ }^{[7,18-22]}$ These changes can also be related to polymer degradation during the aging process due to temperature changes and humidity, ${ }^{[8]}$ or the exposure to chemical products during disinfection. It was observed that the groups polished by glaze presented more color changes than the mechanical polished groups.

There are still controversies regarding the color stability parameters. Canadas et al., ${ }^{[24]}$ Goiato et al. (2013), ${ }^{[20]}$ and Mundim et al. ${ }^{[25]}$ stated that chromatic changes $(\Delta \mathrm{E})$ superior to 3.3 are clinically unacceptable, whereas other authors established this value at 3.715. All groups in this study presented visually perceptible chromatic changes, and the 
Goiatoa, et al.: Glaze polishing technique for acrylic resin

glaze polishing presented the most clinically unacceptable $\Delta \mathrm{E}$ [Table 2].

The glaze behaves differently from the resin when submitted to different disinfectant solutions. Different studies also reported color change of acrylic resin when submitted to different cleansing solutions. ${ }^{[26,27]}$ Both disinfection methods were performed at an elevated temperature, which could induce an

\begin{tabular}{|c|c|c|c|}
\hline Polish & Disinfection & Initial & Final \\
\hline \multirow[t]{2}{*}{ Mechanic } & Microwave & $1.75(0.57)^{\mathrm{A}, \mathrm{a}}$ & $1.94(0.65)^{\mathrm{Ba}}$ \\
\hline & Efferdent & $1.86(0.65)^{\mathrm{A}, \mathrm{a}}$ & $2.70(1.04)^{\mathrm{A}, \mathrm{a}}$ \\
\hline \multirow[t]{2}{*}{ With glaze } & Microwave & $2.28(0.70)^{\mathrm{A}, \mathrm{a}}$ & $2.49(1.03)^{\mathrm{A}, \mathrm{a}}$ \\
\hline & Efferdent & $2.42(0.92)^{\mathrm{A}, \mathrm{a}}$ & $2.42(0.91)^{\mathrm{A}, \mathrm{a}}$ \\
\hline
\end{tabular}

Means followed by the same capital letter in the column do not difference $(P<0.05$, Tukey). Means followed by the same lowercase letter in line do not difference $(P<0.05$, Tukey) additional monomer release that could interact with the glaze coat, thus, increasing the chromatic alteration [Table 2]. The period of use can alter or remove this external coating, ${ }^{[28]}$ but it is believed that the glaze underwent a chemical reaction from the increased temperature or disinfection methods.

The pigment addition also influenced the $\Delta \mathrm{E}$, and prevented the color change for the group polished by glaze [Table 3]. Goiato et al. (2013) ${ }^{[20]}$ also found that the pigment addition at a concentration of $7 \%$ reduced the color alteration for the acrylic resin. The purple pigment used in the present study contains titanium in its composition, which is used in the formula of many sunscreen solutions because of its protective properties. ${ }^{[20]}$

The composition of the acrylic resin and built-up substances can also influence the color stability, especially if the surface roughness is elevated. ${ }^{[8,28,29]}$ The exposure to moisture during the manipulation process, or the incorrect polymerization cycle, can lead to greater porosity, compromising the physical

\begin{tabular}{|c|c|c|c|c|c|}
\hline Variation & SS & df & MS & $F$ & $P$ \\
\hline Resin & 1499.421 & 1 & 1499.421 & 94.551 & $<0.001 *$ \\
\hline Pigment & 48.943 & 1 & 48.943 & 3.086 & 0.081 \\
\hline Polish & 17914.402 & 1 & $17,914.402$ & 1129.654 & $<0.001^{*}$ \\
\hline Disinfection & 0.248 & 1 & 0.248 & 0.016 & 0.901 \\
\hline Resin $\times$ pigment & 1.557 & 1 & 1.557 & 0.098 & 0.754 \\
\hline Resin $\times$ polish & 1396.761 & 1 & 1396.761 & 88.078 & $<0.001 *$ \\
\hline Resin $\times$ disinfection & 9.746 & 1 & 9.746 & 0.615 & 0.434 \\
\hline Pigment $\times$ polish & 0.178 & 1 & 0.178 & 0.011 & 0.916 \\
\hline Pigment $\times$ disinfection & 17.647 & 1 & 17.647 & 1.113 & 0.293 \\
\hline Polish $\times$ disinfection & 1.685 & 1 & 1.685 & 0.106 & 0.745 \\
\hline Resin $\times$ pigment $\times$ polish & 13.580 & 1 & 13.580 & 0.856 & 0.356 \\
\hline Resin $\times$ pigment $\times$ disinfection & 4.685 & 1 & 4.685 & 0.295 & 0.588 \\
\hline Resin $\times$ polish $\times$ disinfection & 0.013 & 1 & 0.013 & 0.001 & 0.977 \\
\hline Pigment $\times$ polish $\times$ disinfection & 26.190 & 1 & 26.190 & 1.651 & 0.201 \\
\hline Resin $\times$ pigment $\times$ polish $\times$ disinfection & 1.429 & 1 & 1.429 & 0.090 & 0.764 \\
\hline Entre amostras & 2283.596 & 144 & 15.858 & & \\
\hline Period & 250.597 & 1 & 250.597 & 11.440 & $0.001 *$ \\
\hline Period $\times$ resin & 13.276 & 1 & 13.276 & 0.606 & 0.438 \\
\hline Period $\times$ pigment & 12.356 & 1 & 12.356 & 0.564 & 0.454 \\
\hline Period $\times$ polish & 523.896 & 1 & 523.896 & 23.917 & $<0.001^{*}$ \\
\hline Period $\times$ disinfection & 44.119 & 1 & 44.119 & 2.014 & 0.158 \\
\hline Period $\times$ resin $\times$ pigment & 214.163 & 1 & 214.163 & 9.777 & $0.002 *$ \\
\hline Period $\times$ resin $\times$ polish & 2.470 & 1 & 2.470 & 0.113 & 0.738 \\
\hline Period $\times$ resin $\times$ disinfection & 23.773 & 1 & 23.773 & 1.085 & 0.299 \\
\hline Period $\times$ pigment $\times$ polish & 26.343 & 1 & 26.343 & 1.203 & 0.275 \\
\hline Period $\times$ pigment $\times$ disinfection & 12.398 & 1 & 12.398 & 0.566 & 0.453 \\
\hline Period $\times$ polish $\times$ disinfection & 0.005 & 1 & 0.005 & $<0.001$ & 0.988 \\
\hline Period $\times$ resin $\times$ pigment $\times$ polish & 52.856 & 1 & 52.856 & 2.413 & 0.123 \\
\hline Period $\times$ resin $\times$ pigment $\times$ disinfection & 7.385 & 1 & 7.385 & 0.337 & 0.562 \\
\hline Period $\times$ resin $\times$ polish $\times$ disinfection & 0.588 & 1 & 0.588 & 0.027 & 0.870 \\
\hline Period $\times$ pigment $\times$ polish $\times$ disinfection & 43.454 & 1 & 43.454 & 1.984 & 0.161 \\
\hline Period $\times$ resin $\times$ pigment $\times$ polish $\times$ disinfection & 6.138 & 1 & 6.138 & 0.280 & 0.597 \\
\hline Intra amostras & 3154.226 & 144 & 21.904 & & \\
\hline
\end{tabular}

$* P<0.05$ means statistical difference. SS: Sum of square, MS: Mean of square 
and esthetical properties of the resin. Therefore, color stability can be enhanced by lower surface roughness and intrinsic

\begin{tabular}{|c|c|c|}
\hline Resin & Mechanic & Glaze \\
\hline Onda Cryl & $20.54(2.18)^{\mathrm{A}, \mathrm{b}}$ & $31.33(5.12)^{\mathrm{B}, \mathrm{a}}$ \\
\hline Lucitone & $24.69(4.29)^{\mathrm{B}, \mathrm{b}}$ & $39.84(6.05)^{\mathrm{A}, \mathrm{a}}$ \\
\hline
\end{tabular}

Table 9: Mean values and (standard deviation) of hardness for each period and polishing technique

\begin{tabular}{lcc}
\hline Period & Mechanic & Glaze \\
\hline Initial & $20.22(4.16)^{\mathrm{A}, \mathrm{b}}$ & $37.75(7.31)^{\mathrm{A}, \mathrm{a}}$ \\
Final & $21.01(2.36)^{\mathrm{A}, \mathrm{b}}$ & $33.42(6.05)^{\mathrm{B}, \mathrm{a}}$ \\
\hline
\end{tabular}

Means followed by the same capital letter in the column do not difference $(P<0.05$, Tukey). Means followed by the same lowercase letter in line do not difference $(P<0.05$, Tukey) porosity. ${ }^{[28]}$ The glaze groups presented worse roughness results, which corroborates with the color stability results.

Surface roughness is a characteristic directly dependent on the finishing and polishing techniques. ${ }^{[14]}$ Therefore, the roughness parameter (Rt) was also assessed to clarify whether the surface treatment, glaze or mechanical, could influence the structural properties of acrylic resins. The glaze polish aims to even out the surface of the material, but some of the glaze polishing groups presented higher roughness values [Table 5], suggesting that the glaze surface in not as smooth as expected. ${ }^{[8,12,28]}$

On the other hand, the glaze maintained the initial roughness properties better, even after the disinfection, suggesting that it is a more stable polish than the sandpaper sequence [Table 6]. The roughness of the mechanically polished samples disinfected with Efferdent increased, and the SEM and AFM images illustrate the surface degradation [Figure 2]. The glaze polish prevented the surface degradation, suggesting that this polish forms a protective superficial coat.

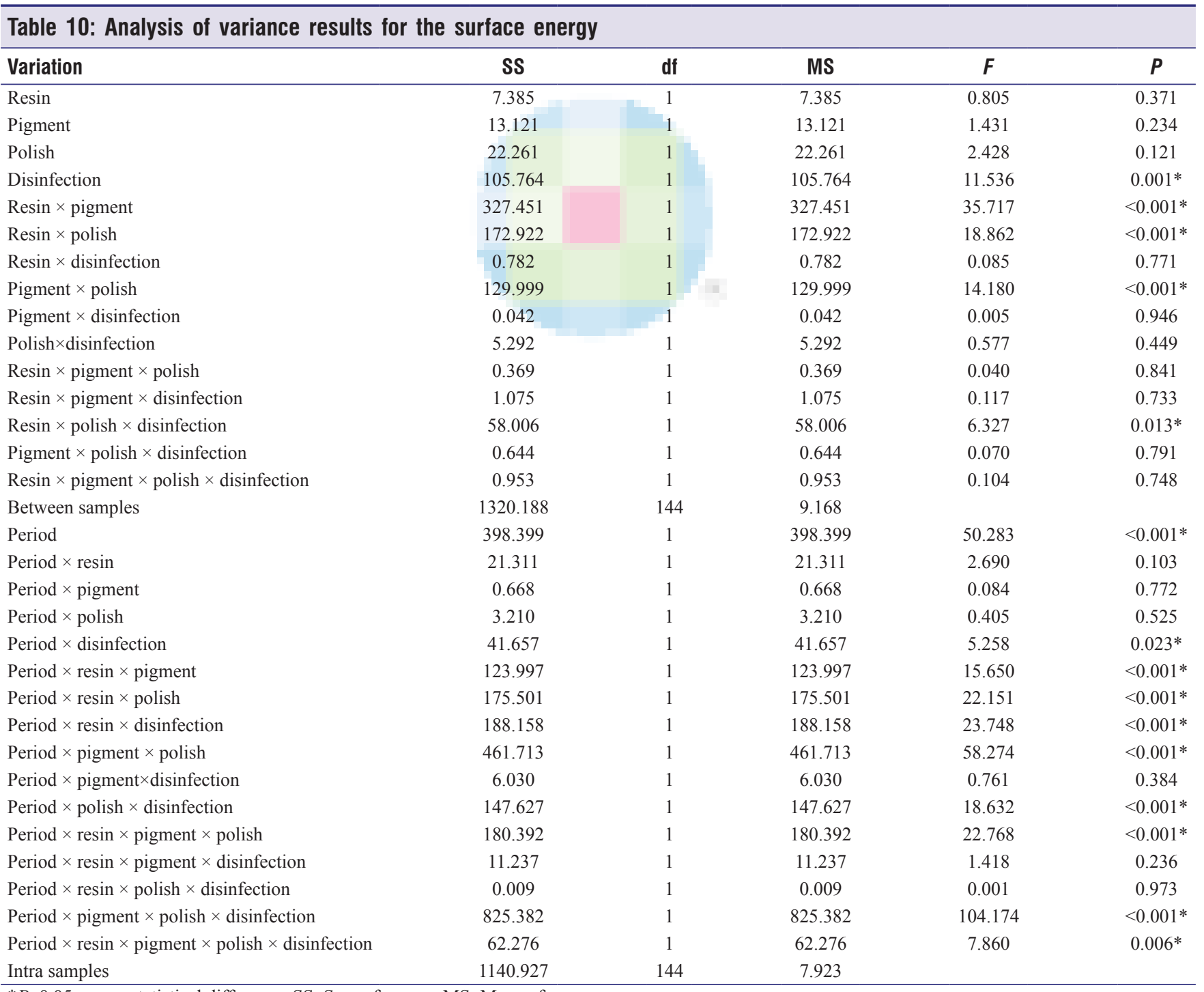

${ }^{*} P<0.05$ means statistical difference. SS: Sum of square, MS: Mean of square 
It is important that the surface of acrylic resin used to manufacture prostheses be free of irregularities, to avoid bacterial colonization and injuries to the underlying tissues that could lead to inflammation of the oral cavity of the patient. ${ }^{[8,24]}$ An even surface cannot always be maintained; it depends on storage conditions and the cleaning habits of the patient. When not ideal, these can cause damage and scratches to the surface that facilitates bacterial growth, and harms the esthetics and longevity of the prosthesis..$^{[5]}$

The microwave disinfection did not affect the roughness results for either polishing techniques, whereas the Efferdent increased the results for the mechanical polish [Table 6]. The manufacturer reports that the Efferdent tablets promote oxygen release to reduce debris and light stains on the surface. This procedure might have a deleterious effect on the surface, causing hydrolysis and decomposition of the resin, reducing the hardness, and increasing the surface roughness. ${ }^{[12]}$

Another property related to the longevity of prostheses is the surface hardness of the acrylic resin; greater hardness indicates higher resistance to abrasives and wear. ${ }^{[5,12,30]}$ There was a difference in surface hardness between the brands evaluated. Lucitone 550 presented significantly higher results than Onda-Cryl [Table 8]. These results were possibly influenced by the material composition and the higher molecular weight of the resin. ${ }^{[3,5,31]}$

The groups polished by glaze presented higher surface hardness values, but this difference was not maintained after the disinfection. Although the glaze results remained higher than

\section{Table 11: Mean values and (standard deviation) of} surface energy for period and disinfection

\begin{tabular}{lcc}
\hline Period & Microwave & Efferdent \\
\hline Initial & $37.28(5.02)^{\mathrm{B}, \mathrm{b}}$ & $39.15(3.97)^{\mathrm{B}, \mathrm{a}}$ \\
Final & $40.23(3.96)^{\mathrm{A}, \mathrm{a}}$ & $40.66(3.43)^{\mathrm{A}, \mathrm{a}}$ \\
\hline
\end{tabular}

Means followed by the same capital letter in the column do not difference $(P<0.05$, Tukey). Means followed by the same lowercase letter in line do not difference $(P<0.05$, Tukey) the mechanical polish, there was a decrease in the hardness values after the disinfection [Table 9]. Braun et al. ${ }^{[21]}$ found that the mechanical polish had better hardness results than the chemical polish, ${ }^{[21]}$ but the chemical polish in their study was performed through the immersion of the acrylic resin in a heated monomer.

According to Fernandes et al. ${ }^{[5]}$ the surface hardness of acrylic resin should be between 16 and $22 \mathrm{KHN}$, since higher values impede the occurrence of cracks, reducing microbial colonization. The results of the current study are within these values, and the glaze polish presented hardness values $\geq 33$ $\mathrm{KHN}$ even after the disinfection, suggesting that its protective coat improved the hardness properties of the acrylic resin. This could increase the longevity of prostheses polished by this solution.

The polish did not affect the surface energy results, only the disinfection and period did [Table 10]. The samples presented lower wettability before the disinfection assay, and the microwave disinfection increased the surface energy results. The lower the surface energy, the greater the adherence and biofilm accumulation. ${ }^{[15]}$ Thus, the disinfection, especially using microwaves, proved to increase the surface resistance to biofilm accumulation.

The SEM and AFM images presented a surface difference for the polishes in the initial period, in which the glaze surface was smoother ${ }^{[28]}$ but there was no difference between the resins tested [Figure 1]. The disinfection considerably degraded the surface integrity; There was a difference on the surface in the initial period [Figure 1] and after the disinfection [Figures 2 and 3], especially for the Efferdent disinfection [Figure 2].

The study limitations were that only one type of chemical polish was tested. There are new materials manufactured for this purpose, and more disinfection procedures could be applied. There are still some controversies regarding the glaze polish and further studies should be performed to validate

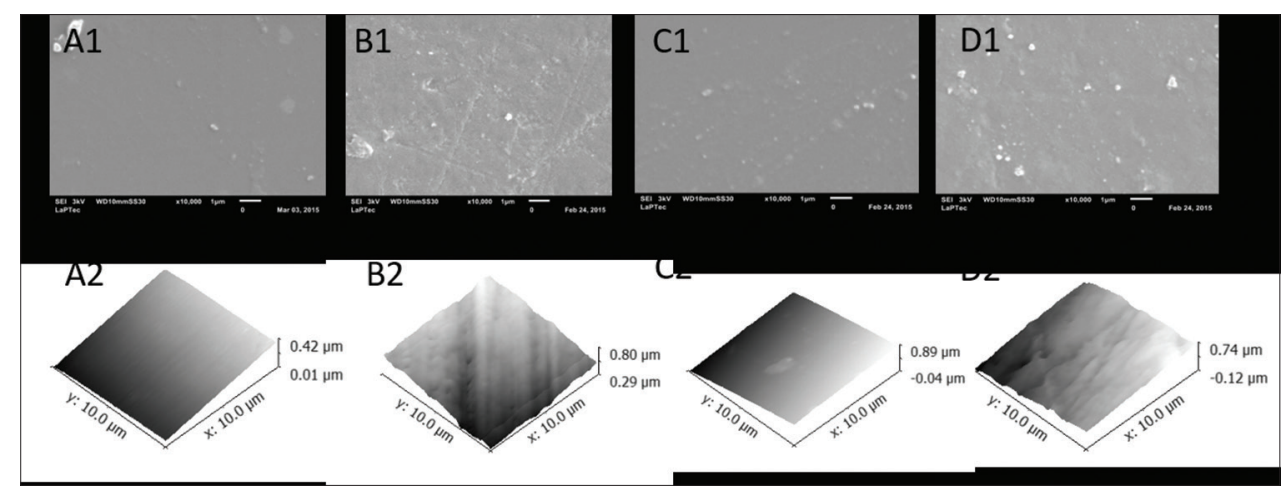

Figure 1: A1, AFM image of Onda Cryl acrylic resin with photopolymerized glaze. B1, MEV image of Onda Cryl acrylic resin with photopolymerized glaze. C1, AFM image of Onda Cryl acrylic resin without photopolymerized glaze. D1, MEV image of Onda Cryl acrylic resin without photopolymerized glaze. A2, AFM image of Lucitone acrylic resin with photopolymerized glaze. B2, MEV image of Lucitone acrylic resin with photopolymerized glaze. C2, AFM image of Lucitone acrylic resin without photopolymerized glaze. D2, MEV image of Lucitone acrylic resin without photopolymerized glaze. AFM: Atomic force microscopy 


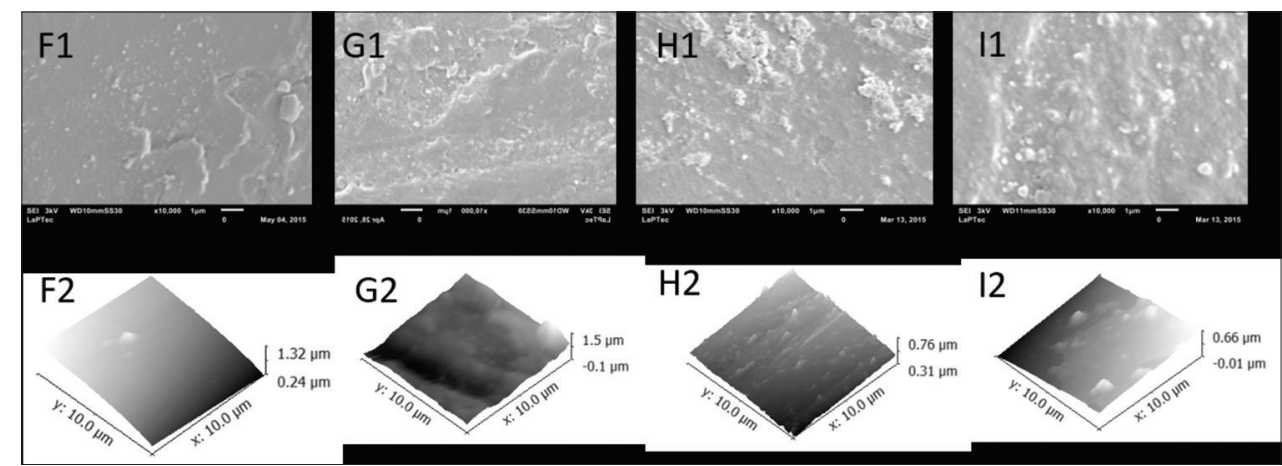

Figure 2: F1, AFM image of Onda Cryl acrylic resin with glaze - Efferdent. G1, MEV image of Onda Cryl acrylic resin with glaze - Efferdent. H1, AFM image of Onda Cryl acrylic resin without glaze-Efferdent. I1, MEV image of Onda Cryl acrylic resin without glaze - Efferdent. F2, AFM image of Lucitone acrylic resin with glaze - Efferdent. G2, MEV image of Lucitone acrylic resin with glaze - Efferdent. H2, AFM image of Lucitone acrylic resin without glaze - Efferdent. I2, MEV image of Lucitone acrylic resin without glaze - Efferdent. AFM: Atomic force microscopy

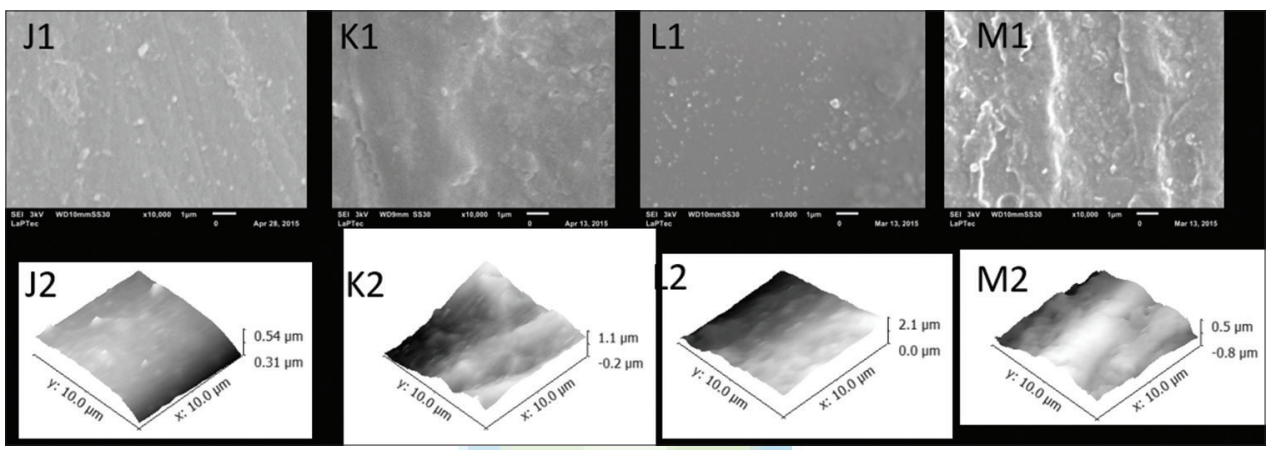

Figure 3: J1, AFM image of Onda Cryl acrylic resin with glaze - Microwave Energy. K1, MEV image of Onda Cryl acrylic resin with glaze - Microwave Energy. L1, AFM image of Onda Cryl acrylic resin without glaze - Microwave Energy. M1, MEV image of Onda Cryl acrylic resin without glaze - Microwave Energy. J2, AFM image of Lucitone acrylic resin with glaze - Microwave Energy. K2, MEV image of Lucitone acrylic resin with glaze - Microwave Energy. L2, AFM image of Lucitone acrylic resin without glaze - Microwave Energy. M2, MEV image of Lucitone acrylic resin without glaze - Microwave Energy. AFM: Atomic force microscopy

its clinical use, such as toxicity to the oral tissues, since the material was first developed for provisional restorations and there no records of long term use.

This study evaluated the disinfection effect on mechanical properties of the resin, future research could evaluate the same groups for antimicrobial effect of different disinfection solutions on the different polishing techniques or to evaluate the microorganism adhesion on the surface of the glaze polish tested. Furthermore, clinical tests could be performed to assess further information on this new polish.

\section{Conclusion}

Based on the results of this study, the photopolymerized glaze improved most characteristics of the acrylic resin, such as the surface hardness and roughness, but did not affect the surface wettability. The absence of characterization pigments in the acrylic resin is inadequate for color stability. When the mechanical properties are considered, the microwave disinfection method promoted better results than the Efferdent tablets.

\section{Acknowledgments}

The authors would like to acknowledge the State of Sao Paulo
Research Foundation (FAPESP) for financial support (protocol 2013/24039-3).

\section{Financial support and sponsorship}

Nil.

\section{Conflicts of interest}

There are no conflicts of interest.

\section{REFERENCES}

1. Lai CP, Tsai MH, Chen M, Chang HS, Tay HH. Morphology and properties of denture acrylic resins cured by microwave energy and conventional water bath. Dent Mater 2004;20:133-41.

2. Goiato MC, Zuccolotti BC, Haddad MF, Moreno A, Pesqueira AA, Gennari HF, et al. The effect of disinfection techniques on the flexural strength of thermopolymerisable acrylic resins with or without pigment addition. Eur J Prosthodont Restor Dent 2015;23:193-8.

3. Goiato MC, dos Santos DM, Moreno A, Iyda MG, Rezende MC, Haddad MF, et al. Effect of disinfection and storage on the flexural strength of ocular prosthetic acrylic resins. Gerodontology 2012;29:e838-44.

4. Cakan U, Kara HB. Effect of liquid polishing materials on the stainability of bis-acryl interim restorative material in vitro. J Prosthet Dent 2015;113:475-9.

5. Fernandes AU, Goiato MC, dos Santos DM. Effect of weathering and thickness on the superficial microhardness of acrylic resin and ocular button. Cont Lens Anterior Eye 2009;32:283-7. 
6. Goiato MC, Dos Santos DM, Baptista GT, Moreno A, Andreotti AM, Bannwart LC, et al. Effect of thermal cycling and disinfection on colour stability of denture base acrylic resin. Gerodontology 2013;30:276-82.

7. Goiato MC, Dos Santos DM, Baptista GT, Moreno A, Andreotti AM, Dekon SF, et al. Effect of thermal cycling and disinfection on microhardness of acrylic resin denture base. J Med Eng Technol 2013;37:203-7.

8. Kuhar M, Funduk N. Effects of polishing techniques on the surface roughness of acrylic denture base resins. J Prosthet Dent 2005;93:76-85.

9. Santos DM, Commar BC, da Rocha Bonatto L, da Silva EV, Sônego MV, Rangel EC, et al. Surface characterization of polymers used in fabrication of interim prostheses after treatment with photopolymerized glaze. Mater Sci Eng C Mater Biol Appl 2017;71:755-63.

10. Santos DM, Nagay BE, da Silva EV, Bonatto Lda R, Sonego MV, Moreno A, et al. In vitro analysis of different properties of acrylic resins for ocular prosthesis submitted to accelerated aging with or without photopolymerized glaze. Mater Sci Eng C Mater Biol Appl 2016;69:995-1003.

11. Rao DC, Kalavathy N, Mohammad HS, Hariprasad A, Kumar CR. Evaluation of the surface roughness of three heat-cured acrylic denture base resins with different conventional lathe polishing techniques: A comparative study. J Indian Prosthodont Soc 2015;15:374-80.

12. Moreno A, Goiato MC, dos Santos DM, Haddad MF, Pesqueira AA, Bannwart LC, et al. Effect of different disinfectants on the microhardness and roughness of acrylic resins for ocular prosthesis. Gerodontology 2013;30:32-9.

13. Silva MJ, de Oliveira DG, Marcillo OO, Neppelenbroek KH, Lara VS, Porto VC, et al. Effect of denture-coating composite on Candida albicans biofilm and surface degradation after disinfection protocol. Int Dent J 2016;66:86-92.

14. Gungor H, Gundogdu M, Yesil Duymus Z. Investigation of the effect of different polishing techniques on the surface roughness of denture base and repair materials. J Prosthet Dent 2014;112:1271-7.

15. Haralur SB. Evaluation of efficiency of manual polishing over autoglazed and overglazed porcelain and its effect on plaque accumulation. J Adv Prosthodont 2012;4:179-86.

16. Hamedi Rad F, Ghaffari T, Tamgaji R. Evaluation of the color stability of methyl methacrylate and nylon base polymer. J Dent (Shiraz) 2017; 18:136-42.

17. Shinawi LA. Effect of denture cleaning on abrasion resistance and surface topography of polymerized CAD CAM acrylic resin denture base. Electron Physician 2017;9:4281-8.

18. Lohitha K, Prakash M, Gopinadh A, Sai Sankar AJ, Sandeep CH, Sreedevi B, et al. Color stability of heat-cure acrylic resin subjected to simulated short-term immersion in fast-acting denture cleansers. Ann
Med Health Sci Res 2016;6:291-5.

19. Gandhi N, Daniel S, Benjamin S, Kurian N, Varghese VS. Evaluation of surface microhardness following chemical and microwave disinfection of commercially available acrylic resin denture teeth. J Clin Diagn Res 2017;11:ZC87-91.

20. Goiato MC, Zuccolotti BC, dos Santos DM, Sinhoreti MA, Moreno A. Effect of intrinsic nanoparticle pigmentation on the color stability of denture base acrylic resins. J Prosthet Dent 2013;110:101-6.

21. Braun KO, Mello JA, Rached RN, Del Bel Cury AA. Surface texture and some properties of acrylic resins submitted to chemical polishing. J Oral Rehabil 2003;30:91-8.

22. Rao DC, Kalavathy N, Mohammad HS, Hariprasad A, Kumar CR. Evaluation of the surface roughness of three heat-cured acrylic denture base resins with different conventional lathe polishing techniques: A comparative study. J Indian Prosthodont Soc 2015;15:374-80.

23. Ferracane JL. Hygroscopic and hydrolytic effects in dental polymer networks. Dent Mater 2006;22:211-22.

24. Canadas MD, Garcia LF, Consani S, Pires-de-Souza FC. Color stability, surface roughness, and surface porosity of acrylic resins for eye sclera polymerized by different heat sources. J Prosthodont 2010;19:52-7.

25. Mundim FM, Antunes PL, Sousa AB, Garcia LF, Pires-de-Souza FC. Influence of artificial accelerated ageing on the colour stability of paints used for ocular prosthesis iris painting. Gerodontology 2012;29:e312-7.

26. Goiato MC, Nóbrega AS, dos Santos DM, Andreotti AM, Moreno A. Effect of different solutions on color stability of acrylic resin-based dentures. Braz Oral Res 2014;28:1-7.

27. Freitas Oliveira Paranhos Hd, Bezzon OL, Davi LR, Felipucci DN, Silva CH, Pagnano VO, et al. Effect of cleanser solutions on the color of acrylic resins associated with titanium and nickel-chromium alloys. Braz Oral Res 2014;28:1-7.

28. Rutkunas V, Sabaliauskas V, Mizutani H. Effects of different food colorants and polishing techniques on color stability of provisional prosthetic materials. Dent Mater J 2010;29:167-76.

29. Gad MM, Fouda SM, ArRejaie AS and Al-Thobity AM. Comparative Effect of Different Polymerization Techniques on the Flexural and Surface Properties of Acrylic Denture Bases. Journal of Prosthodontics. 2017. doi:10.1111/jopr.12605.

30. Goiato MC, dos Santos DM, Gennari-Filho H, Zavanelli AC, Dekon SF, Mancuso DN, et al. Influence of investment, disinfection, and storage on the microhardness of ocular resins. J Prosthodont 2009;18:32-5.

31. Fernandes AU, Goiato MC, Dos Santos DM. Effect of weathering and thickness on roughness of acrylic resin and ocular button. Cont Lens Anterior Eye 2010;33:124-7. 